\title{
Exploring the Form and Function of Dissident Irish Republican Online Discourses
}

\author{
Lorraine Bowman-Grieve \\ University of Lincoln, UK \\ Maura Conway \\ Dublin City University, Ireland
}

\begin{abstract}
This article seeks to contribute to broadening the focus of research in the area of violent online political extremism by examining the use of the internet by dissident Irish Republicans and their supporters. The argument here is not that the internet substitutes face-to-face contacts amongst Irish Republicans, including violent dissidents, nor that it currently plays a central role in processes of radicalisation into violent dissident groups, but that it has an important support function in terms of providing an 'always-on' space for discussion, consumption, and production of Irish Republicanism and thus a potentially useful educative role in terms of introducing 'newbies' to violent dissident Republicanism while also acting as a 'maintenance' space for the already committed. This exploratory study considers the importance of these functions in the context of repeated suggestions that the dissidents have no significant support-base or constituency as internet activity certainly gives the appearance of some such support.
\end{abstract}

\section{Keywords}

dissidents, forums, internet, Irish Republicanism, terrorism, websites, Web 2.0

\section{Introduction}

The Irish Republican Army's (IRA) violent decades-long campaign to oust Britain from Northern Ireland and create a united Ireland was ended in 2005 when the IRA's Army Council announced an end to its armed campaign and, shortly after, completed decommissioning its weapons. The Northern Ireland conflict had already officially been brought to a halt by the Irish and UK government with the signing of the Good Friday Agreement-officially the 'Belfast Agreement'-in 1998. There are a number of IRA splinter groups, however, that remain committed to a united Ireland, wrought by violent means if necessary. Breakaway or splinter Irish Republican terrorist groups are generally known as 'dissidents' or, in common parlance, 'the Dissidents'. Horgan and Morrison (2011) employ the term 'violent dissident Republicans' (VDR) to draw attention to the fact that there are also non-violent dissidents; the acronym VDR and the term 'dissidents' will be used interchangeably herein.

Research into violent online jihadism mushroomed after 9/11, from almost nothing prior to that time, and with the effect of pushing research into other areas of violent online political extremism off the agenda. The amount of online content promoting violent politics is increasing all the time, however, and is not limited to purveyors of any one political ideology. This exploratory study seeks to contribute to broadening the focus of research in the area of violent online political extremism and setting an agenda for future research in this area by examining the use of the internet by dissident Irish Republicans and their supporters. The argument here is not that the internet substitutes 
face-to-face contacts amongst Irish Republicans, including dissidents, nor that it currently plays a central role in processes of radicalisation into VDR groups, but that it has an important support function in terms of providing an 'always-on' space for discussion, consumption, and production of Irish Republicanism and thus a potentially useful educative role in terms of introducing 'newbies' to VDR ideology and potentially interesting them in 'real world' activity while also acting as a 'maintenance' space for the already committed. These functions are particularly important if, as repeatedly pointed out in the media (Breen, 2010: N27; Connolly, 2007: 11) and by policymakers (Armstrong, 2008: 7; Irish Examiner, 2009) and security practitioners (Associated Press, 2009) that the dissidents have no significant support base or constituency in Ireland, North or South, as it certainly gives the appearance of some such support.

\section{Background on dissident Irish Republicanism}

VDRs are characterised by: (a) their refusal to sign-up to the Good Friday Agreement (1998) that officially ended the Northern Ireland conflict - commonly known as 'the Troubles'; (b) their rejection of the successor agency to the Royal Ulster Constabulary (RUC), the Police Service of Northern Ireland (PSNI), as a legitimate law enforcement agency for Northern Ireland; and (c) their commitment to the continued use of violence to expel the British presence from the 'six counties' and the establishment of a united Ireland. There are three main VDR organisations currently in existence: the Real IRA (RIRA), the Continuity IRA (CIRA), and Óglaigh na hÉireann (ONhE), all of which share the above commitments, but disagree on a slate of other matters (Frampton, 2011; Horgan and Morrison, 2011: 643-645).

The CIRA emerged out of the 1986 split within Provisional Irish Republicanism that also resulted in the establishment of their political wing Republican Sinn Féin (RSF), although the paramilitary wing of the Continuity dissidents did not engage in attacks until the mid-1990s. The split occurred as a result of the Provisional IRA's (PIRA) acceptance of the so-called dual approach of 'the armalite and the ballot box', which referred to their continued commitment to violent struggle while at the same time ceasing their policy of abstensionism[1] (see Frampton, 2011: 47-53). The RIRA was formed more than a decade later when a further group of Irish Republicans, including the PIRA's Quartermaster General, Michael McKevitt,[2] split from the PIRA. Those who split in 1997 denounced the leadership of the PIRA and Sinn Féin who were, at that time, involved in peace negotiations with the British government, which the RIRA dissidents believed was a betrayal of core Republican ideals.

The 32 County Sovereignty Movement (32CSM) broke with Sinn Féin at the same time as the RIRA. Originally led by Bernadette Sands-McKevitt-sister of deceased IRA member, hunger-striker, and elected UK MP Bobby Sands and wife of Michael McKevitt- the 32CSM is commonly held to be the political wing of the RIRA. One of the RIRA's earliest and most renowned attacks, which they are alleged to have carried out in conjunction with the CIRA, was the 15 August 1998 Omagh bombing, which killed 29 people and injured 220 more. The intensely negative response to this incident left the dissidents with little support or sympathy within Irish Republican communities in either Northern Ireland or the Republic of Ireland, and there were no dissident bomb attacks_-or even attempted bomb attacks — and only 14 VDR attacks in total carried out in 1999, only 2 of which were post-Omagh (Horgan and Morrison, 2011: 646, 649). This lull in dissident violence was not to last, however. 
There has been a steady annual uptick in attacks by VDRs in the last decade. The renewed dissident threat was underlined when, in just a 48-hour period, in March 2009, the dissidents claimed responsibility for two separate attacks resulting in three murders. On 7 March, the Real IRA shot and killed two British soldiers, while on 9 March the Continuity IRA shot dead Stephen Carroll, a member of the Police Service of Northern Ireland (PSNI). In this period too, internal conflicts within the CIRA and RIRA resulted in the formation of additional dissident factions. Somewhat confusingly, the two most notable of these new groups both style themselves Óglaigh na hÉireann.[3] One of these is a splinter from the CIRA in Strabane, Co. Tyrone and the other arose out of a larger national-level split in the RIRA. It was thought up until quite recently that the RIRA's ONhE faction did not have a political wing, but this belief underwent revision when the 'political pressure group' Republican Network for Unity (RNU) used the opportunity provided by their 2011 Árd Fheis (national convention) to send 'comradely greetings to Óglaigh na hÉireann’ (Horgan and Morrison, 2011: 644; see also Frampton, 2011: 218224).

When taken together, all three paramilitary organisations-CIRA, RIRA and ONhE_-are said to have some 600 presently active members (Moriarty, 2010), although this is disputed by some (Moloney, 2011). Regardless of their numbers, 'an escalation of low-level terrorist activity by Irish Republican splinter groups has recently reached its highest level in ten years' (Horgan and Morrison, 2011: 642-643). In 2010, this low-level activity consisted of 46 shootings and punishment attacks, 16 petrol bombings, 10 assaults, 8 arson attacks, and 5 violent robberies (p. 651). There were also 73 dissident bombing incidents in 2010, with 41 devices defused by security agencies and a further 32 devices actually detonated (Horgan and Morrison, 2011: p. 649). Thence the UK and Irish Independent Monitoring Commission description of VDRs, in its final report in 2011, as 'brutally active’ (p.13).[4]

\section{Online Irish Republicanism}

Between 1966 and 1999, 'the Troubles' that convulsed Northern Ireland (pop. 1.5 million) cost 3600 lives and left another c. 40,000 people seriously wounded. In 1999, just one year after the Good Friday Agreement brought an official end to the conflict, just 11 per cent of all Northern Ireland Heads of Household reported having internet access via home computer. By 2009 - 2010, this had risen to 59 per cent.[5] In the space of a decade then, Northern Ireland's internet landscape transformed. Today, all of Northern Ireland's political parties maintain an internet presence as do a range of other socio-political actors, including residents associations, Orange Lodges, and marching bands. It is unsurprising, therefore, that Irish Republicans of various sorts are also represented online, doubly so if one considers that the latter have a long history of media activism, including establishing their own mass-media outlets, such as the Irish Republican newspaper An Phoblacht (Republican News); established in 1970, An Phoblacht claims to have been 'the first paper in Ireland to go online'.[6]

'The IRA is unquestionably the most heavily studied terrorist organisation of the past forty years' (Silke, 2007: 84) and yet there is a dearth of research into Irish Republicans' online presence. This may be explained by a number of factors, including the low levels of internet access in Northern Ireland at the official cessation of the conflict and the narrow attention by researchers focused on the terrorism-internet relationship to violent jihadis' internet strategies as a result of the events of 11 September 2001 . Nevertheless, the PIRA's Army Council only officially ended their armed campaign in 2005, at which time both the VDR threat and the changed internet landscape in Northern 
Ireland and, indeed, worldwide, were already becoming apparent. Some Irish Republican groups have fairly lengthy histories online; Dartnell's (2001) analysis of the 'enationalism of the Irish Republican Socialist Movement (IRSM)' is an early attempt at sketching one such group's internet presence and purpose. Reilly has written extensively on Northern Irish terrorist groups' use of the internet, to include Loyalist online activism (Reilly, 2006: 125-132; 2011). In fact, Reilly’s Framing the Troubles Online (2011) is the only book-length treatment of any aspect of Northern Ireland's internet landscape. In terms of research into the dissidents' online presence, however, just one journal article (Bowman-Grieve, 2010) and one book chapter (Nalton et al., 2011) have been published to date; this article updates and extends upon the analyses contained in these.

\section{Internet discussion forums}

While support for Irish Republicanism in general is plentiful online, it can be more difficult to get a real sense for distinct groups such as the RIRA and the CIRA. Websites in support of Irish Republicanism are largely broadcast in nature, which is in keeping with research findings on the structuring of the official websites of other ethno-nationalist terrorist groups and their affiliates (Conway, 2005). Online discussion forums officially representing any one Republican paramilitary organisation remain elusive too. Table 1 is a modified and updated version of a table that appeared in Nalton et al.'s (2011: 128) chapter 'Radicalization and internet propaganda by dissident Republican groups in Northern Ireland since 2008' and identifies the key internet discussion forums currently trafficked by Irish Republicans, including VDR supporters. Those forums that have no data recorded in the column 'Members in August 2011' are no longer operational. It will be noticed, however, that those forums still in existence have all increased their registered memberships since Nalton et al collected their data in 2010, with 'Up the Ra!'[7] in particular showing a huge jump in members.

Table 1. Irish Republican internet discussion forums: Membership data

\begin{tabular}{lcccc}
\hline Web forum & $\begin{array}{l}\text { Members } \\
\text { in April } \\
2010\end{array}$ & $\begin{array}{l}\text { Members } \\
\text { in August } \\
2011\end{array}$ & $\begin{array}{l}\text { Growth } \\
\text { (\%) }\end{array}$ & $\begin{array}{l}\text { Most users } \\
\text { ever online }\end{array}$ \\
\hline $\begin{array}{l}\text { Irish Republican } \\
\text { http://www.irishrepublican.n } \\
\begin{array}{l}\text { Irish Freedom News } \\
\text { http://www.irishfreedomnews.com }\end{array}\end{array}$ & 11,754 & 15,336 & 23.3 & 745 \\
$\begin{array}{l}\text { Irish Republican Socialist Forum } \\
\text { http://rsmforum.proboards.com/index.cg }\end{array}$ & 1,667 & 1,953 & 14.6 & 169 \\
$\begin{array}{l}\text { Up the RA! } \\
\text { http://upthera.free-forums.org/ }\end{array}$ & 336 & 1,117 & 69.9 & 88 \\
$\begin{array}{l}\text { Irish Republican Bulletin Board } \\
\text { http://admin2.7.forumer.com/ } \\
\text { Irish-Nationalism }\end{array}$ & 1,209 & 1,408 & 14.1 & 133 \\
$\begin{array}{l}\text { http://www.irish-nationalism.net } \\
\text { Ireland's Future } \\
\text { http://irelandsfuture.free-forums.org }\end{array}$ & 1,364 & - & - & 339 \\
\hline
\end{tabular}

Previous research (Bowman-Grieve, 2010) identified the Irish Republican Bulletin Board as a virtual arena in which Irish Republicans of various stripes-including supporters of the PIRA, CIRA, 32CSM, RIRA, Irish National Liberation Army (INLA), 
etc.-communicate with each other, share ideas and views, disseminate information and propaganda, and critique Northern Irish politics in general and Republicanism in particular. This virtual community, while frequented by a varied group of individuals with a range of Republican views, has direct online links to $\mathrm{Na}$ Fianna Éireann (Irish Republican Youth Movement) that is in turn linked, both virtually and in the 'real world', with Republican Sinn Féin (RSF), whose paramilitary wing is the CIRA. By far the most popular of all the various web-based Republican forums, however, is the Irish Republican forum. This forum is an example of a 'closed' virtual community that requires user registration to both view and contribute posts to most areas within the forum. Registering parties are required to provide details of their political affiliation and recommendations from already registered members are requested, although it is not clear if this is a formal registration requirement. The forum currently has over 15,300 registered members and over 66,700 discussion threads organised into sections with titles such as 'Breaking News', 'Main Discussion Forum', 'Political Prisoners', 'Groups', 'International Debate' and 'Media'.

Web-based discussion forums such as the Irish Republican Bulletin Board and the Irish Republican forum are being used to create and disseminate discourses that support, critique and promote the ideology and traditions of Irish Republicanism, in both its present-day and historical guises. What can be discovered here is not so much how Irish Republicans view themselves, as per traditional hierarchical structures of presentation (i.e. top-down) apparent on 'official' websites, but rather how members, supporters, and sympathisers of these movements presently interpret Irish Republicanism and the rhetoric and actions of both Irish Republican politicians and paramilitaries. These interactive online spaces therefore showcase the evolving face of Irish Republicanism made up of what are variously referred to within these online milieus as 'die-hards', 'true Republicans', 'dissidents' and even 'sell-outs' and 'traitors'.

Familiarity with the propaganda literature of the Irish Republican movement is considered essential reading for anyone interested in being a 'true' Republican supporter, with different types of propaganda literature advised for consultation by different categories of users. 'New users' or 'newbies', for example, are encouraged to read basic texts, such as histories of Ireland and the 1916 Rising, progressing onto more recent writings relating to 'the Troubles' and continuing to the current movement and its political context. This propaganda provides justifications and validation for community members and their views and may be a contributory factor in increasing levels of ideological control among group members and also in contributing to early stages of a radicalisation process. At the core of the discussion forums, however, is discourse relating to contemporary issues. Both the Irish Republican Bulletin Board and the Irish Republican Forum, for example, provide access to breaking news stories relating to Northern Ireland with items of interest posted by users often as conversation starters which lead, in some cases, to lengthy and heated debates.

The types of news topics posted range from general political news to news directly relevant to Republicans and their supporters. On the Irish Republican Forum 'Breaking News' section, for example, responses to a thread entitled 'Roadside Bomb' (started 10 July 2010) relating to a bomb believed to have been detonated in South Armagh included concern for civilians and IRA members ('Let's hope no civilian has been injured, and a safe passage home too [sic] the volunteers'), speculation as to its purpose ('What do you think it was for then? It was obviously meant for PSNI car coming along and wither [sic] it went premature or, more likely, after giving it some days whoever had planted it set it off rather than abandon it') and commentary on its goals in relation to 
Republican propaganda ('Sounds like a major propaganda [sic] success if it was republicans ... the fact that they have shown that the police cannot police in what is suppose [sic] to be a "normalised state"').

The range of activities, besides engagement in online discussion and debate about Irish Republicanism, encouraged as part of a process of cyber-based involvement can take many forms including, for example, purchasing Irish Republican memorabilia from online stores such as that advertised on the sign-in page of the Irish Republican forum.[8] Also of interest are Republican texts, videos, and still images and the trading of information relating to where these are available to download. Access to copies of The IRA Green Book is often of interest to online Republican supporters too.[9] The sale of Irish Republican memorabilia and the trading of literature and other materials online is important not just in terms of the money such sales might generate for the movement, but in relation to its function for the individual. Being able to make purchases online allows individuals to contribute monetarily to the Republican movement, which is important in terms of the way in which it allows individuals to become more active in their support of Irish Republicanism. Many of the highest level contributors to the Irish Republican forum, including those identified as 'Moderators' and 'Administrators', also sport virtual 'Donator' 'badges', for example. Making online donations or donating to Republican online projects, along with purchasing Republican memorabilia, and exchanging online content information are activities that arguably facilitate increasing support and potentially violent radicalisation processes.

\section{Social networking sites and Web 2.0}

Web 2.0 facilitates autonomous, up-to-the-minute communication not just by terrorist groups or movements, but also individuals who claim to support and represent these groups and movements. It is this user-generated aspect of contemporary terrorist media, that utilises the internet to encourage and sustain support for both traditional terrorist movements and evolving ideologies, that needs to be thought through more thoroughly by researchers. It might be argued that where once auto-propaganda was internally focussed and distributed from the top down-particularly in groups with hierarchical organizational structures - the internet allows contemporary terrorist movements, who often have a decentralised structure, to cast a wider net in terms of the range and type of content they disseminate. Not only is supportive content being created and disseminated by movement leaders — such as via the 32CSM's official websites[10] — but increasingly, and due to the nature of the internet as a user-directed environment, violent extremist content is increasingly user-generated and disseminated both to and by a range of internet users who represent different levels of support and commitment to given political violence movements.

There is a large amount of content supportive of VDR accessible via YouTube, FaceBook, and Twitter. In addition to the 'official' 32CSM presence and other 'official' dissident content posted on YouTube, there are large numbers of 'fan' videos also uploaded. Much of the content of these videos echoes the themes apparent in the larger VDR online milieu, as discussed below. So too does the content of videos produced by various online media collectives, such as Free Derry Media, which had videos from various Irish Republican organisations, including dissidents, posted on its YouTube channel before it was suspended. An interview with Free Derry Media quoted them as describing their purposes as motivating youth to embrace Irish Republicanism and educating 'those abroad who are curious' (Nalton et al., 2011: 126). Dissidents and their supporters are also active on FaceBook; [11] according to Fermanagh 32CSM website, the 
official 32CSM FaceBook page was removed following complaints.[12] Republican Network for Unity (RNU) is active on both Twitter and Flickr; @RepublicanUnity had 152 Tweets and 217 Twitter followers in August 2011, while RNU’s Flickr account had over 200 photos posted.

\section{Dissident Irish Republicanism's virtual discursive structuring}

The heterogeneous, but interlinked 'cyberspaces' described above together constitute a small part of a vast Irish Republican online milieu, a portion of which may be described as the VDR online milieu. Across websites, forums, blog postings, YouTube and Facebook, a number of themes emerge that are central discursive features of the latter. These are identified and analysed below.

\section{Attaching blame and justifying violence}

As Wright (1991: xi) argues, terrorist organisations must present the proof that their use of violence is justifiable; that the organisation's ‘ideological objectives are important enough to justify the adoption of a terrorist strategy to achieve them'. The justification of terrorism is fundamental for the organisation if they hope to influence an audience with the goal of gaining either sympathy or support. A key step in this process is for the terrorists to attach blame for starting the conflict to the enemy while claiming for themselves the moral high ground (Finch, 2000: 378). For example, a press release (21 April 2010) on the 32CSM's 'Documents' website entitled 'Irish broad front movement' contains the following statement:

We believe Britain is mercilessly pursuing its war objectives under the banner of 'peace', these objectives are the stabilisation of British state rule in Ireland and an attempt to assimilate Republican resistance into structures which neutralise any assertion of the people of Ireland to sovereignty and national self determination.

Terrorist propaganda traditionally relies heavily on portraying the perceived enemy as being guilty or responsible for the 'need' to use terrorism. In Irish Republican propaganda, the British government, military and the Loyalist community in Northern Ireland are often held responsible for the conflict in terms of not only its historical origins - often going back in history to the Irish Famine (1845-1852) or, at the very least, the 1916 Rising - but also for its maintenance over time, including current problems in the peace process. Not only is blame and responsibility firmly located at their doorstep, but this is in turn used as a justification for all and any actions and activities to further the 'fight for Irish freedom'.

This long-running narrative has been internalised by dissident Irish Republicans and their supporters. The following example is contained in a blog posting by 'Newry Republican’ on Blogspot (28 April 2010):

Yet again we have concrete proof of the unchanged nature of British policing in Ireland. This unchanged force are [sic] still using the tactics they have always used. Their history of framing and attempting to set up Republicans is well known .... [relates details of a Belfast youth being 'forced' by police to 'set-up' local Republicans] ...This proves once again that the RUC/PSNI is unchangeable ... Yet despite all of this, former comrades continue to support the enemies of Ireland, and call for people to turn informer on Irish Republicans.

In another post appearing on the Irish Republican Forum, in a thread entitled 'Ammo found: Five men arrested over moving explosives over border’ (started 10 July 2010), a 
community member makes the following statement, which doesn't just seek to justify ongoing violence, but ongoing violence in the face of what he or she admits is the withdrawal of community support:

In a sense I agree, community support is vital, some communities are giving support. But overall republicans never had the support of the majority of the people, they have always acted against the expressed wishes of the Irish people ... doesn't mean they are wrong. In a way I agree, armed struggle was used on a massive scale by those groups and they failed, so I can't see how todays [sic] groups are going to be victorious, but at the end of the day as long as the occupation remains Irishmen and women have the legitimate right to oppose that by any means including armed action. (emphasis added)

This is in keeping with the content of, amongst other documents available online, the 32CSM's Constitution, a portion of which reads as follows:

(f). That recognising the denial of national sovereignty to the Irish people through British occupation of part of the national territory; we hold that all administrations and assemblies purporting to act as lawful government for the Irish people, or otherwise functioning as partitionist entities, to be illegal under international law as they usurp Irish sovereignty.

(g). We hold that it is both a right and a duty of all Irish people to uphold Irish sovereignty.

(h). We reaffirm the right of the Irish people to use all legitimate means necessary to restore National Sovereignty as declared in the [Irish] Declaration of Independence 1919. [13]

\section{Responses to the term 'dissidents'}

Some of the strongest responses across VDR websites, forums and blogs are in response to the use of the term 'dissidents' to describe members and supporters of the CIRA, RIRA, ONhE and affiliated groups. As early as 2002, Irish Republicans were questioning the use of the term dissident online:

The Provisionals have no right to continue to call themselves Republican and persistently misappropriate the historic names of Sinn Féin and the IRA which they continue to use without authorisation. The 32CSM and the so-called 'Real IRA' should also drop their claim to being the true torch-bearers of Republicanism as they remained with the Provisionals for 12 years after they had sold out Republicanism. We in the Republican Movement are not 'dissidents'. (quote from the Irish Republican Bulletin Board, cited in Bowman-Grieve, 2006)

'Certain people like to term people like myself as dissenters, but we haven’t dissented any Republican principles ... I believe today the same things I always believed in', asserts 'Newry Republican’ on BlogSpot. [14]

'Guestbook':

A similar point was made by a contributor to the now-defunct Tyrone 32CSM

Sinn Fein do not care about anyone but them selves as long as there getting there big fat cheques. We as Irish republicans and should not respect the name of dissident we are true republicans. Sinn Fein should be the dissidents they do not represents the people of Ireland as a hole. They are scumbags. I would urges every man that reads this to stand up and put these people in there place [sic]. [15] 
The divisions within Irish Republicanism are raised repeatedly by dissidents and their supporters, in particular their unhappiness with the role of Sinn Féin as the official political representatives of Irish Republicanism within mainstream politics. The latter are viewed by dissidents, who clearly view themselves as the only remaining 'true Republicans', as 'sell outs'. For example:

sinn fein no longer represent me in any way ... because i no longer support them i would now be labelled by them as a dissident republican. this is a term which i loathe as my republican ideals are unchanged and sf ideals have changed drastically [sic].

Thence the names chosen by VDR groups to describe themselves: the 'real' IRA and the 'continuity' IRA, for example.

It is worth drawing attention at this point to the use of 'euphemistic language' (Bandura, 1990) in many of the forum postings reproduced in this article. The label 'terrorism' or 'terrorist' is never used by members of Irish Republican discussion forums or within support websites. On the internet discussion forums, other Irish Republicans are sometimes referred to as 'comrades' or 'a chara', which is Gaelic for 'friend', and those involved in violent activism as 'volunteers'. The Northern Ireland conflict and the use of terrorism by Republican paramilitaries is referred to as the 'armed struggle'. This is not surprising given what we know about terrorist movements in general and specifically the perceptions of those involved in violence, i.e. that they are not terrorists, but rather 'freedom fighters' or 'soldiers'; thence the Irish Republican 'Army'. This may seem obvious, but it is an important distinction to flag as it allows individual members or supporters to psychologically distance themselves from the negative connotations of 'terrorism' by allowing them to shift the guilt and responsibility for their actions back onto their adversaries and affords them the opportunity to justify and legitimate their continued support for and/or involvement in political violence.

\section{Critiquing VDR strategy}

The dissidents, while clearly retaining a certain level of support online also find themselves the subject of continued scrutiny and debates as to whether violent Republicanism can actually achieve the aim of a united Ireland. In the following examples, from the Irish Republican Forum, [16] members of the wider Irish Republican online community voice opinions unpopular with dissidents:

[T]here's no support or sympathy for armed action in the current climate ... There's no winning in this, its quite clear where the support of the community lies in this struggle, and the way things are going, its only a mater of time before lives are lost. There's no way that the PSNI or Gardai are going to allow small bands of republicans taking pot shots at them, killing and injuring officers, when other groups such as the Irps [17] and Provos have recognised that its not the way to go [sic].

And in another response regarding levels of support for the dissidents:

There is a significant minority of support in core republican areas, but its not the level of support needed to maintain a long war. ... the majority of the community are backing the Provos in successive elections as a clear show of opposition to the current low intensity armed struggle [sic]. 
Also, while many VDR openly deride Sinn Féin representatives online, responses such as the following regarding rioting that took place in the Ardoyne area of Belfast in April 2010 are also common:

Are you for real? He [18] didn't condemn anybody for opposing it-he condemned those who were only there to start trouble. Political mouth piece against the nationalist community? Sinn Féin have been firmly endorsed by the overwhelming majority of the Nationalist and Republican community while anti-[Good Friday Agreement] groups have been routinely rejected. I'd consider groups whose goalsis [sic] to remilitarize the north, remove Republicans influence in local government and pull the Brits back onto the streets to be the ones acting against the nationalist community.

\section{Linking online Irish Republicanism and 'real world' activism}

Direct exhortations to violence are relatively rare within both the general Irish Republican online milieu and its dissident sub-sections. Instructions on carrying out violent attacks, such as are common within the 'jihadisphere' (Ducol, 2012), are non-existent. In terms of 'real world' activism, the emphasis is on supporting Republican prisoners and attending Republican commemorations of various sorts. The latter points to the likelihood that many of both the producers and consumers of VDR online content are resident in either Northern Ireland or the Republic of Ireland and therefore in a position to attend at gatherings in either or both locales. This heavy emphasis on not just virtual support, but opportunities for face-to-face interactions probably means that there is less of a need on the part of VDR to post potentially sensitive information online than there is for other more widely-dispersed political violence movements.

Other reasons for avoiding detailing violence strategies online may range from concerns that such discussions increase one's likelihood of contravening the 'Terms of Service' of one's service provider and thus having one's account or even one's entire website or channel expunged by the service (Nalton et al., 2011: 126) to being prosecuted under various provisions of the UK Terrorism Act (2000 and 2006) (Reilly, 2011: 178). A user with the screen name 'Flemmy1916', whose YouTube video uploads in support of the RIRA are referred to by Nalton et al. (2011: 125) and are no longer available on the site, contributed the following to a thread with the title 'Question: Facebook hacked' on the Irish Republican forum in April 2011:

Got a message from facebook [sic] today saying the following; 'You made a wall post that violated our Terms of Use. Among other things, posts that are hateful, threatening or obscene are not allowed. We also take down posts that attack and individual or group... Continued misuse of Facebook's features could result in your account being disabled'... More censorship from Facebook [sic]. [19]

Even in the absence of direct discussion of violence strategies, the online VDR 'scene' nevertheless offers the security services, Sinn Féin, Loyalists and others an opportunity to monitor what issues, activities and strategies are the subject of both agreement and dispute amongst dissidents, which is potentially useful to opponents. In fact, the whole of the online Irish Republican community is concerned with the potential infiltration of Republican online spaces by, in particular, British intelligence agencies as reflected in threads devoted to this issue in various online discussion forums. Comments such as 'Stay off facebook [sic] people. It's the greatest intelligence tool the CIA ever invented' and 'MI5 onto ya?', contained in the same thread regarding Facebook as mentioned above, are representative. 
Support for Republican prisoners, incarcerated due to their involvement in Republican and terrorist activities and also termed 'Prisoners of War' (PoWs), is a consistent theme on both traditional Irish Republican and dissident websites and discussion forums. Individuals are encouraged to show their support and demonstrate their commitment to the Irish Republican movement by writing letters to those imprisoned and by signing petitions seeking recognition of their status as PoWs. Dedicated websites have been established to this end, for example Irish Republican Socialist Prisoners, Irish Republican Prisoners Welfare Association, and Republican Prisoners Action Group.[20] Marches and protests in support of prisoners are frequent, with their times and locations routinely posted on websites and within internet discussion forums.

\section{Conclusion}

The heyday of the Provisional IRA pre-dated the web, but this did not stop the emergence of a vibrant Irish Republican community on the internet. Dissident Irish Republicans, in particular, have a burgeoning online presence. Websites, discussion forums and social network pages and profiles are being generated by supporters of the VDR movement, with discussion forums in particular becoming popular social spaces where users can discuss and disseminate content that supports the ideals and goals of the dissidents. With growing levels of support evident online via social networking sites, which are heavily populated by teens and young adults who were born after the ceasefires that led to the Good Friday Agreement, the escalating scale of dissident attacks, and the dissidents' stated mission of thwarting the Northern Ireland Peace Process, it is clear that in-depth research into the online strategies of dissident Irish Republicans is now warranted. We foresee this research falling into two broad categories, namely that concerned with the role of the internet in processes of violent radicalisation, on the one hand, and that concerned with Irish Republicanism, and its variants, on the other.

The internet provides a space for the dissemination of dissenting views and discussion and debate around these. The historically factionalised nature of Irish Republicanism continues to present itself in contemporary manifestations of the movement so that what we find online are both narratives of support for VDR and counter-narratives in support of non-violent Republicanism. Support for a 'United Ireland' does not necessarily equate to support for violent action, even amongst 'the Dissidents'. [21] This article highlights the need for researchers to more closely examine who the dissidents are and what they believe. VDR are routinely described as having 'no politics' (Armstrong, 2008: 7; Belfast Telegraph, 2009: 26; Connolly, 2007: 11; Irish Examiner, 2009), analysis of VDR online spaces can contribute knowledge of their selfunderstanding. With this in mind, we suggest a more systematic assessment in future research of the online Irish Republican spaces described herein. A critical thematic analysis (Antony and Thomas, 2010; Van Zoonen et al., 2011) of the comments on a single discussion forum or comparative research on a selection of forums seems to us to be a productive next step in terms of fleshing-out points of agreement and disagreement amongst various categories of Irish Republicanism, including VDRs, and even amongst varieties of 'dissidence'.

The above suggestions for future research would probably tell us more about Irish Republicanism than about the workings of the internet or, indeed, the integration of the two (i.e. Irish Republicanism and the internet). The second major area of research to which research on online Irish Republicanism, particularly online VDR, could contribute then is in the burgeoning field of studies into processes of violent online radicalisation, which has been dominated to date by studies into violent jihadis' online strategies. The 
link between the Irish Republican cyberspaces described herein and real world action is tenuous, particularly as this relates to translation into violent action. Perhaps VDR online activity amounts to little more than VDR sympathisers confirming the thoughts and feelings of each other while also encouraging non-violent resistance through, for example, letter writing, petitioning and attendance at protests. It is increasingly assumed by policymakers and others that the internet plays a significant role in violent jihadism and extreme Right activity, but what is its role in VDR? How does the cyber activism of the extreme Right compare and contrast with that of VDRs? Are the online strategies of violent jihadis and VDRs similar or do they diverge significantly? And what, if anything, can this tell us about the role of the internet in violent extremism in general and its potential for effecting a return to 'the Troubles' in Northern Ireland, in particular?

\section{Notes}

1. 'Abstentionism' is the term used to describe the policy of standing for election to a deliberative assembly while refusing to take up any seats won or to otherwise participate in the parliament's business; it has been employed by Irish Republicans in numerous UK and Irish elections since the early 19th century.

2. A website declaring the innocence of McKevitt, who was convicted in 2003 by the Republic of Ireland's Special Criminal Court for terrorist offences and sentenced to twenty years imprisonment, can be found at http://www.michaelmckevitt.com (accessed 25 September 2011).

3. Variously translated as 'Soldiers of Ireland', 'Youth of Ireland', 'Irish Volunteers'.

4. The Independent Monitoring Commission was established by the UK and Irish Governments in 2004 to monitor paramilitary activity in Northern Ireland. It published 26 reports on this activity before being wound-up in March 2011.

5. See Table 4.11 'Internet Access via home computer by sex and religion of head of household, 1999 to 2009-10' in the Continuous Household Survey undertaken by the Northern Ireland Statistics and Research Agency. Available at: http://www.csu.nisra.gov.uk/Internet_access_via_home_computer_by_sex_and_derived_religio n_of_head_of_household_trend.htm (accessed 12 September 2011).

6. 'About Us, Part Four'. Available at: http://aprnonline.com/?page_id=154 (accessed 12 September 2011).

7. This is a colloquialism that is used to show support for the IRA (i.e. 'Up the IRA').

8. 'Shamrock Superstore'. Available at: http://www.shamrocksuperstore.net (accessed 12 September 2011).

9. The IRA Green Book is available on the Irish Republican Forum, via a thread started 08/06/2008 entitled 'The IRA's Green Book'. Available at: http://www.irishrepublican.net/forum/showthread.php?18482-The-IRA-s-Green-Book (accessed 12 September 2011).

10. The 32CSM has two main websites: their 'In Defence of the Nation' site (URL: www.32csm.info) and their 'Documents' site (URL:

www.freewebs.com/32csmdocuments/index.htm), and a number of regional websites representing the six counties of Northern Ireland and some counties within the Republic (both websites accessed 1 September 2011).

11. The Irish Republican forum's FaceBook page currently has 687 'likes'.

12. Available at: http://32csmfermanagh.blogspot.com/2010/08/political-censorship-fromfacebook.html (accessed 1 September 2011).

13. Available at: http://www.freewebs.com/32csmdocuments/constitution.htm (accessed 1 September 2011).

14. Available at: http://newryrepublican.blogspot.com/ (accessed 1 September 2011).

15. Formerly available at: http://www.32csmtyrone.com/apps/guestbook/ (accessed 8 September 2011 but no longer accessible). 
16. Both from thread entitled 'Ammo Found: Five Men Arrested Over Moving Explosives Over Border’ (started 10 July 2010).

17. 'Irps' refers to the Irish Republicans Socialist Party or IRSP.

18. Referring to Sinn Féin Assembly member Gerry Kelly and his comments regarding the situation in Ardoyne.

19. Available at: http://www.irishrepublican.net/forum/archive/index.php/t61792.html?s=6f132e61aa0a02a0eb5906168d90dfc1 (accessed 12 September 2011).

20. Available at: http://www.irsm.org/irspows/; http://irpwa.blogspot.com/; http://www.freewebs.com/powstatusnow/ (accessed 25 September 2011).

21. See, for example, Anthony McIntyre’s blog 'The Pensive Quill'. Available at: http://thepensivequill.am/ (accessed 25 September 2011). 